\title{
Role of Gastrokine 1 in Gastric Cancer
}

\author{
Emilia Rippa ${ }^{1}$, Paolo Mallardo $^{1}$ and Paolo Arcari ${ }^{1,2}$ \\ ${ }^{1}$ Department of Biochemistry and Medical Biotechnologies, \\ University of Naples Federico II, \\ ${ }^{2}$ CEINGE, Advanced Biotechnologies scarl, Naples \\ Italy
}

\section{Introduction}

Gastric cancer (GC) has high incidence (> 1.000.000 new cases/year) and mortality rate in several countries and is still one of the most frequent and lethal (> $600.000 \mathrm{dead} /$ year) neoplasia with an average survival of five years (less than 20\%) (Pisani et al., 1990; Lands et al., 1998). It is already well known that infection of gastric antrum mucosal with the bacterium Helicobacter pylori is the cause of the chronic inflammation that leads to intestinaltype gastric cancer in the majority of the cases. The H. pylori infection is widespread but only a small number of the total population of infected individuals might eventually develop adenocarcinoma (around 3/10,000 individuals per year or $2.1 \%$ for lifetime infection) (Correa \& Piazuelo, 2008). Risk factors influencing the outcome of $H$. pylori-associated pathology include bacterial cytotoxic heterogeneity, diet, and geographic differences. The phenomenon of decreased gastric cancer incidence in Africa compared with other regions where H. pylori is endemic (Holcombe, 1992) is probably due to the different diet of these populations compared to the western countries. This discrepancy has been partially attributed to helminth co-infection that likely modifies the characteristic proinflammatory type 1 T-helper 1 cell response, to a T-helper 2-predominant response (Whary et al., 2005), typified by the release of non-inflammatory cytokines and reduced incidence of $H$. pyloriassociated glandular atrophy, an early marker of cancer development. The identification of novel genes regulated by $H$. pylori in vivo, particularly those contributing to these early stages of gastric cancer, would facilitate improved understanding of the differential susceptibility to this pathogen. The different susceptibility among individuals to $H$. pylori infection is still not yet defined. Some works, however, suggested that the polymorphisms in host genetic factors like the proinflammatory cytokines interleukin-1, interleukin-8, and tumor necrosis factor may play a relevant role (El-Omar et al., 2003).

The evolution of intestinal tumours is characterized by a progression of several sequential steps that starts with gastritis and then progresses to mucosal atrophy (atrophic gastritis), intestinal metaplasia, dysplasia and carcinoma with subsequent metastatic dissemination (Correa, 1992, 1995). The diffuse-type has instead a poorer prognosis and develops through unknown genetic and morphological events from normal gastric epithelium. No preceding steps have been identified in the pathogenesis of diffuse carcinoma other than the chronic gastritis. The pathogenesis of gastric cancer remains poorly understood although it is 
evident that several environmental factors, such as $H$. pylori infection can be one of the causes leading to this disease. In fact, the risk to develop gastric cancer is increased in patients with $H$. pylori infections probably as the result of a combination of genetic and environmental factors in which the infection by $\mathrm{H}$. pylori is of particular relevance, especially when the inflammation involves the gastric body region with respect to the antrum (Correa, 1995; Goldstone et al., 1996; Nabewera \& Logan, 1999). Generally, this condition is associated to different degrees of atrophy and alterations of the secretor function that, in the long term, became associated to gastric carcinoma (Forman et al., 1991; Parsonnet et al., 1997; Watanabe et al., 1998).

Diffuse adenocarcinoma shows an increased propensity for intra and transmural spread and is therefore associated with a poorer prognosis. Unfortunately, the histological classification of an individual gastric adenocarcinoma is not clear-cut with a tumour often comprising a mixture of intestinal and diffuse tissue types. Under these considerations, we think that there is an urgent necessity to dispose of an efficient tool for the detection of early stage gastric cancer like the identification of highly sensitive and specific biomarkers that will aid disease diagnosis and ensure early clinical intervention, thereby preventing mortality and reducing morbidity (Boussioutas \& Taupin, 2001). Since most of GC (around 73\%) is developed at antrum/pylorus, proteins secreted by antrum/pylorus mucosa might play a critical role in maintaining normal gastric mucosa structure and function.

\section{Expression of gastrokine 1 in normal and malignant tissues}

From a comparative proteomic analysis of human specimens of gastric mucosa from patients with and without $H$. pylori infection, we have shown the differential expression of several up- and down-regulated proteins (Rippa et al., 2007). One of these proteins, gastrokine 1 (GKN1), a novel stomach-specific protein also known as $18 \mathrm{kDa}$ antrum mucosa protein (AMP-18 or foveolin) (Oien et al., 2004), was highly expressed in normal tissues and markedly down-regulated in samples derived from $H$. pylori infected patients (Nardone et al, 2007). To elucidate the biological function of GKN1, we have characterized its expression in normal and malignant gastric tissues also by immunohistochemical technique. The etiology of most gastric cancers is multifactorial and the pathogenesis is believed to involve a multi-step process in which the normal gastric epithelium evolves through intermediate pre-malignant lesions (intestinal metaplasia and dysplasia) leading to adenocarcinoma. These investigations were based on the hypothesis that GKN1 expression in pre-malignant gastric tissues and in gastric carcinomas is altered in terms of quantity (reduced amount or complete absence of the protein), quality (altered protein size), and distribution (abnormal cell-type and/or subcellular localization) compared to normal gastric tissues.

\subsection{The gastrokine family}

GKN1 belongs to a family of genes encoding stomach-specific secreted proteins consisting of 3 known members: gastrokine 1 (GKN1) (Martin et al., 2003), gastrokine 2 (GKN2) (Du et al., 2003), and gastrokine 3 (GKN3) (Menheniott et al., 2010). Although their mode of action remains unclear, the recent demonstration of a GKN2/trefoil factor (TFF1) heterodimer in gastric mucus suggests that gastrokines may regulate the extracellular function of TFFs (Westley et al., 2005). 


\subsection{Gastrokine 1}

GKN1 (also named as AMP18), a member of BRICHOS superfamily, is secreted by antrum mucosa (Oien et al., 2004). GKN1 gene of about $6 \mathrm{~kb}$ was reported to be located at 2p13 and contains 6 exons (Martin et al., 2003). Bioinformatics analysis suggested the secretory signal peptide with 20-amino acids presented at the N-terminal and the processed protein consisted of 165-amino acids after cleavage. Despite several asparagine residues in the Nterminal domain, none seems to be the consensus site of traditional glycosylation (Martin et al., 2003). The GKN1 gene encodes a small protein of 185 amino acids containing a Nterminal signal peptide (Yoshikawa et al., 2000). The BRICHOS domain consists of about 100 amino acids and it has been found in several unrelated proteins associated with major human diseases (Sanchez-Pulido et al., 2002) like BRI2, related to familial British and Danish dementia; chondromodulin-I (ChM-I), linked to chondrosarcoma; surfactant protein C (SPC), associated with respiratory distress syndrome; and gastrokine 1 (also known as CA11, AMP18 \& foveolin) (Shiozaki et al., 2001; Martin et al., 2003), linked to gastric cancer (Sanchez-Pulido et al., 2002; Shiozaki et al., 2001). Evaluation of GKN1 expression at mRNA and protein level, by RT-PCR and immunhistochemistry (IHC), was found only in stomach, gastric antrum, but not in esophagus, duodenum, or intestine (Oien et al., 2004).

\subsection{Evaluation of GKN1 expression levels}

The evaluation of GKN1 expression in normal and malignant cells was performed according the following strategy.

\subsubsection{Patients enrolment and clinical characterization}

In this study a population of 28 patients with gastric cancer $(20$ intestinal and 8 diffuse types) was enrolled. Interview focusing on diet and lifestyle habits, family history and other toxic environmental factors was performed. A family history positive for gastric cancer was also carefully verified. The biopsy specimens were taken during an upper video-endoscopy in the gastric body or collected immediately after surgical resection and soon delivered for diagnosis and tissue sampling. Specimens were used for culture test, histological and immunohistochemical tests and for molecular approach.

Gastric biopsy specimens were collected from normal subjects and patients with erosive gastritis, peptic ulcer or gastric cancer, either infected or not infected with $H$. pylori. None of the subjects had taken antibiotics, proton pump inhibitors or nonsteroidal antinflammatory drugs during the preceding 3 months. At least 65 gastric biopsy specimens were taken during upper endoscopy: one pinch was used to measure the urease activity (rapid urease test), and one pinch was used for a histological examination of H. pylori infection using hematoxylin-eosin stain. Three pinches and four pinches were used respectively for protein and RNA extraction. 36 patients (55\%) showed to be negative for H. pylori infection and among these, 31 had normal mucosa while the remaining 5 had minimal infiltration of lymphomonocytes in the lamina propria. H. pylori infection was detected in 29/65 patients suffering from active gastritis ( 25 mild-moderate and 4 severe); 10 patients showed mild or moderate atrophy that was associated in 4 cases with focal antral complete IM. Anti-H. pylori and anti CagA IgG antibodies were not detected in any of the H. pylorinegative subjects but were found in 29 (100\%) and 21 (72\%) H. pylori-positive patients, respectively. 


\subsubsection{Proteomic analysis}

In order to identify proteins differently expressed in human gastric mucosa without and with $H$. pylori infection, proteins extracted from biological specimens were analyzed by $2 \mathrm{D}$ electrophoresis in the $\mathrm{pH}$ range 3-10. Protein samples $(100 \mu \mathrm{g})$ were focused on IPG strips and then separated by $12 \%$ SDS-PAGE. Proteins were stained with Comassie Brilliant Blue G-250. Comassie-stained protein spots were excised from 2-D gels and treated with $10 \mathrm{ng} / \mu \mathrm{l}$ of trypsin and digested overnight at $37^{\circ} \mathrm{C}$ according to Schevechencko et al., 1996. The peptide mixture obtained was then analyzed using a MALDI-TOF mass spectrometer Voyager DETM PRO (Applied Biosystems), operating in positive-ion reflectron mode. Protein identification was achieved using MALDI mass spectral data for a data-base search against the NCBInr database using the Mascot search algorithm, a parameter representing the reliability of protein identification (see also http://www.matrixscience.com/) (Nardone et al., 2007).

Figure 1, shows the protein profiles observed in human gastric mucosa specimens. GKN1 was identified by MALDI-TOF analysis of tryptic fragments (Rippa et al., 2007). On 2D gels, the GKN1 protein spot was found in all samples from H. pylori non-infected patients and it was generally drastically reduced in several samples of $H$. pylori infected tissues. The amino acid sequence of GKN1 isolated from gel covered about $38 \%$ of the entire protein sequence. Mature GKN1 did not contain the first 20 amino acid leader peptide as confirmed by the amino acid sequence of the N-terminal performed by Edman's degradation. As expected from the isoelectric point of the mature protein $(\mathrm{pI}=5.32)$, the migrating position of GKN1 on the $2 \mathrm{D}$ gel was toward acidic $\mathrm{pH}$.

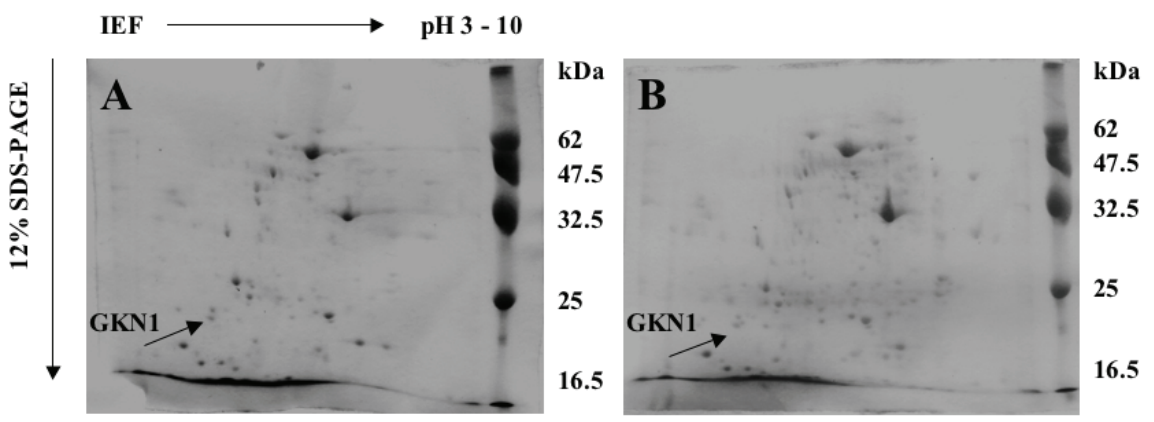

Fig. 1. Bidimensional gel electrophoresis of proteins extracted from gastric endoscopic mucosal samples. A) H. pylori-negative sample, B) H. pylori-positive sample. The firstdimension (isoelectric focusing, IEF) was performed using the Ettan IPGphor (Amersham Biosciences) equipped with $7 \mathrm{~cm}$ strip holders.

To analyze more quickly the expression levels of GKN1 in our collection of samples from patients with and without $H$. pylori infection (45 cases), we first tried to use monodimensional SDS-PAGE followed by staining of the gel with comassie blue. Figure 2 shows 
the position of the GKN1 stained band after electrophoresis at around $18 \mathrm{kDa}$ however this approach resulted only qualitative and not quantitative.

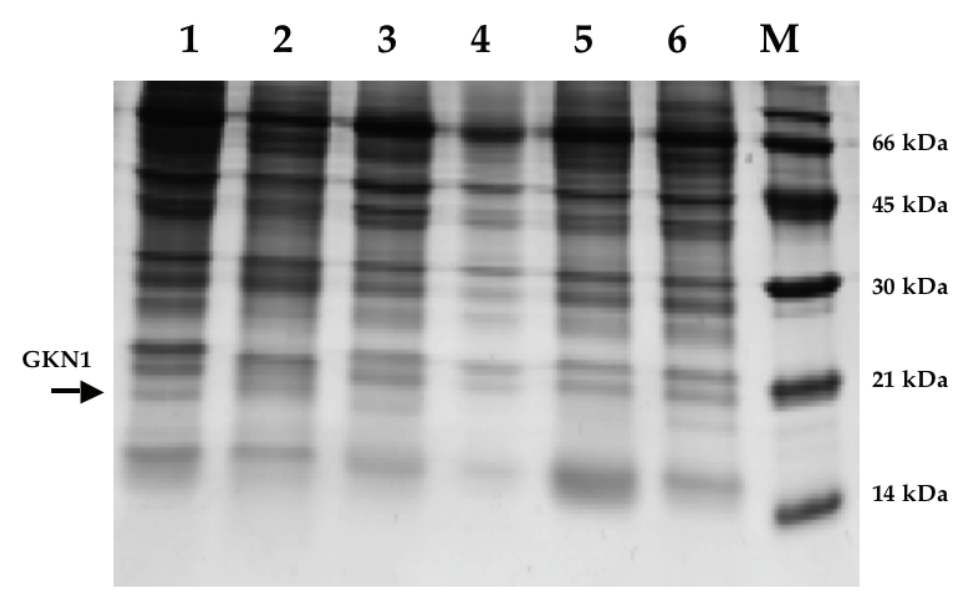

Fig. 2. Monodimensional gel electrophoresis of proteins extracted from gastric endoscopic mucosal samples. SDS-PAGE (14\%) of proteins extracted from gastric endoscopic mucosal samples from $H$. pylori-negative patient (Lanes 1, 3, 5) and H. pylori-positive patient (Lanes 2, 4, 6). M, size markers.

\subsubsection{Western blotting analysis of GKN1 expression}

To detect more precisely the GKN1 expression levels, we adopted the Western blot procedure using a specific anti-GKN1 antibody (Abnova) raised against the intact protein. The analysis was carried out starting from three biopsies. Specimens were mixed with proteases inhibitor (Roche), homogenized and equivalent amounts of protein $(10 \mu \mathrm{g})$ were separated by electrophoresis on sodium dodecyl sulfate- $12 \%$ polyacrylamide gels. After electrophoresis, the proteins were electroblotted to a nitrocellulose membrane (Immobilon PQS). GKN1 protein was identified using a specific rabbit polyclonal antibody (Abnova, diluted 1/50000). Visualization was obtained with an ECL kit (Pirce).

As reported in Figure 3, the reduction in expression levels of GKN1 was not always observed in all patients with $H$. pylori associated gastritis but only in about $20 \%$ of samples. The evaluation has been based on the expression levels of $\beta$-tubulin. In all cases, the reduction of GKN1 levels was about two times that of non-infected samples. Densitometric evaluation of the bands showed a lower level in $H$. pylori-positive patients compared to the $H$. pylori-negative subjects (average: $0.19 \pm 0.02$ vs $0.44 \pm 0.07, \mathrm{p}<0.005$ ). This finding is in agreement to what observed also in another proteomic analysis regarding other proteins/enzymes differentially expressed by H. pylori infection (Baek et al., 2004).

We also analyzed the expression of GKN1 in human specimens derived from patients with gastric cancer. With respect to the non-tumoral area, it was observed that GKN1 expression was consistently down regulated or absent in tumoral area (Nardone et al., 2008). The 28 patients with Gastric Cancer (GC) (20 intestinal and 8 diffuse) showed the following characteristics: the intestinal type was well differentiated in 4 , moderately differentiated in 8 


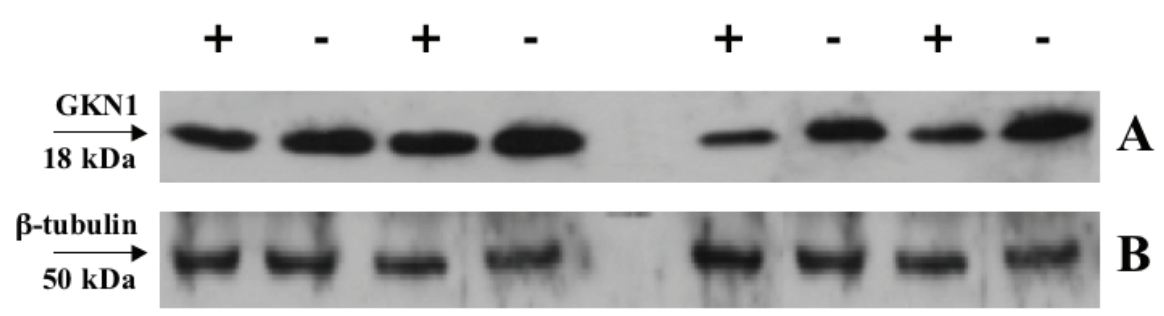

Fig. 3. Western blot analysis of human gastric mucosa samples. About $10 \mu \mathrm{g}$ of protein extracts from samples of gastric mucosa from non-infected patient (-) and patients with $H$. pylori infection $(+)$ were separated on SDS-PAGE and blotted against commercial antibody anti-GKN1 (A) and anti- $\beta$-tubulin (B) (control).

and poorly differentiated in the remaining 8 cases, while four were in the early stage and the remaining 16 in the advanced stage. Diffuse type GC was poorly differentiated and advanced in all cases. The non tumoural areas of intestinal type GC showed a variable degree of gastric atrophy with diffuse IM, instead, the peritumoural areas of diffuse type GC showed a variable degree of non-dysplastic inflammation. H. pylori infection was not revealed in all cases of tumoural areas. It is interesting to point out, however, that $H$. pylori infection was detected, in the peritumoral areas, in 6 cases (4 early and 2 advanced). Anti- $H$. pylori IgG antibodies were detected in 16/20 patients with intestinal histotype GC and in 6 out of 8 with diffuse type GC. Anti-CagA antibodies were detectable in 17/28 cases (14 intestinal and 3 diffuse histotype). Using Western blot (WB) analysis, GKN1 protein expression was not detected in any of the tumoural areas but was revealed instead in nontumoural areas (Fig. 4).

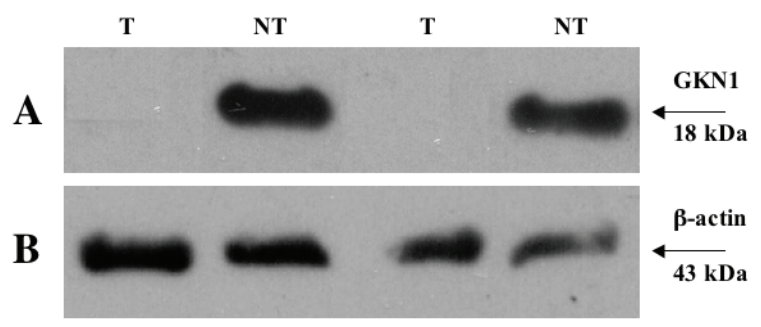

Fig. 4 Western blot analysis of GKN1 expression in human gastric specimens. About $20 \mu \mathrm{g}$ of protein extracts from samples tumoral area $(\mathrm{T})$ and non-tumoral area (NT) were separated on SDS-PAGE and blotted against commercial antibody anti-GKN1 (A) and anti-- $\beta$-actin (B) (control).

\subsubsection{Immunohistochemical analysis of GKN1 expression}

The Immunohistochemical evaluation of GKN1 on surgical specimens was performed on 7micron sections of frozen unfixed gastric tissues. The percentages of immunoreactive cells 
was scored as follows: $0-5 \%=$ negative; $5-25 \%=$ low staining; $25-50 \%=$ moderate staining; $>50 \%=$ intense staining. The results obtained, summarized in Fig. 5 showed the absence of GKN1 in tumor tissues (our actual collection of about 30 cases). In fact, the GKN1 staining was intense in normal gastric tissues, low or completely negative in intestinal metaplasia and gastric cancer, respectively (Fig. 5) (Rippa et al., unpublished results).
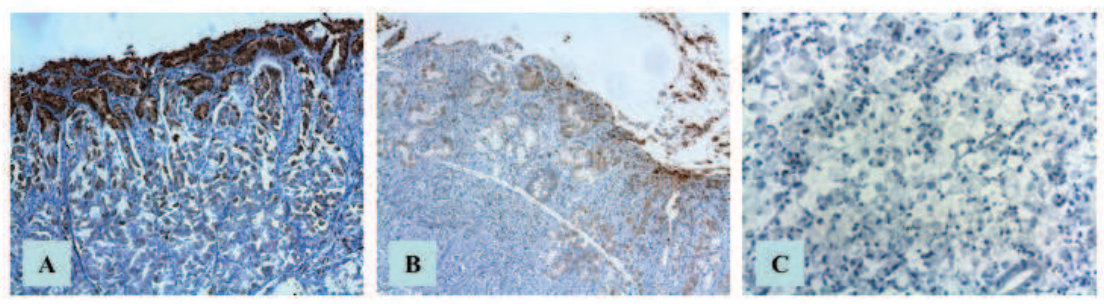

Fig. 5. Representative immunohistochemical images of surgical specimens from: A) Normal gastric tissue (LSAB, orig. magn. X200); B) Intestinal metaplasia (LSAB, orig. magn. x100); C) Intestinal type gastric cancer (LSAB, orig. magn. X200).

In addition, the hystopathological aspect of the tumor specimens correlated to the GKN1 expression with tumor subtype. This observation suggested that GKN1 could play an important role in normal gastric function thus and strongly suggested that GKN1 could be a biomarker for gastric cancer (Yoshihara et al., 2006; Moss et al., 2008).

\section{Functional role of GKN1}

Regarding the functional role of GKN1, there are two questions that are still to be clarified. The first important question is whether GKN1 is secreted from gastric cells. Although data from bioinformatics analysis and the presence in the protein of a leader peptide sequence, there is not a conclusive answer to this point. If GKN1 is secreted from the gastric mucosa cells, other questions will raise up concerning the sequence of the secreted protein and how it interacts with its target cells. The second question is whether and how the GKN1 protein modulates the behavior of gastric cells. To this aim, we started to elucidate the role of the protein in the processes of proliferation and signalling transduction analyzing the expression of GKN1 in gastric carcinoma cells and its effects on apoptosis.

\subsection{Over-expression of GKN1 in gastric cancer cell lines}

The knowledge about the biological function of GKN1 is not completely clarified. What is known at the moment is that GKN1 appears to be important in maintaining mucosal integrity and could play a role in cell proliferation and differentiation. In fact, GKN1 might have a protective effect by increasing accumulation of specific tight and adherens junction proteins and also protecting their loss after injury (Walsh-Reitz et al., 2005). The presence in GKN1 of the BRICHOS domain might explain its protective role. In fact, the BRICHOS is 
present also in another gastric protein GKN2, known also TFIZ1, because of its homology to GKN1. This protein is involved in the binding of tumor suppressor proteins such as the trefoil protein 1 (TFF1). Such interaction could be important in the regulation of the integrity of the mucosa (Bruce et al., 2005; Otto et al., 2006; Baus-Loncar et al., 2007).

The strong down-regulation of GKN1 expression in patients with $H$. pylori infection (Nardone et al., 2007) its absence in gastric cancer (Nardone et al., 2008; Moss et al., 2008) and its absence in human gastric cancer cell lines (AGS and MKN28) (Motoyama et al., 1986; Segal et al., 1996; Oien et al., 2004) are factors that suggest the participation of GKN1 in the host response to $H$. pylori and suggest also that GNN1 can act as gastric tumor suppressor gene (Du et al., 2003). Regarding this point, since GKN1 is highly down-regulated or absent in gastric cancer, one possible explanation of its disappearance could be linked to epigenetic events or loss of heterozygosity, as it was observed for other tumor suppressor genes such as TFF1 (Carvalho et al., 2002). However, as recently reported by Yoon et al., 2010, no significative mutations nor methylation in the GKN1 gene in gastric tumors were found, thus the down-regulation of GKN1 it is likely not depending by epigenetic events.

Toback et al., (2003) proposed that GKN1 could have some mitogenic effects on intestinal epithelial cells (IEC) as compared with EGF 5. Shiozaki et al., 2001, instead found that this protein was able to inhibit proliferation of a human carcinoma cancer cell line (MKN28) cells after transfection. From this finding it emerges that it is important to define the role of GKN1 in the modulation of inflammatory damage or tumorigenesis in the gastric mucosa. Attempts to reduce cancer survival rates include strategies directed towards the identification of specific targets inducing apoptosis in tumor cells.

\subsubsection{Evaluation of transient expression of GKN1 in gastric cancer cell}

AGS or MKN28 cancer cells (Motoyama, et al., 1986) were transfected with the eukaryotic expression vectors pcDNA 3.1 containing the entire GKN1 cDNA. Cells were grown in 5\% $\mathrm{CO} 2$ at $37^{\circ}$ in DMEM (Dulbecco's modified Eagle's medium) and transfected using lipophectamine 2000. After transfection, cell growth and apoptosis was evaluated by cytofluorimetry.

The overexpression of GKN1 in MKN28 or AGS cells, with respect to control cells, reduced cell growth (Rippa et al., 2010). A similar effect was also reported by Shiozaki et al., 2001, who observed a reduction in MKN28 colony formation in cells transfected with CA11 gene with respect to control cells. Also GKN3, the new gastrokine found in mammals, strongly attenuated the growth of GKN3-overexpressing MKN28 cells (Menheniott et al., 2010). Because tissue repair is determined by many signals coming from the local environment, central to this process is the commitment of gastric cells to undergo apoptosis, survive, or proliferate, following inflammation. Therefore, gastric epithelial cell apoptosis could be influenced by GKN1 during the inflammatory process. The Fas-Fas ligand (FasL) system has been recognized as the major pathway for the induction of apoptosis in a variety of human normal and neoplastic cells (Itoh \& Nagata, 1993; Suda et al., 1993; Nagata 1996). The Fas antigen (CD95, APO-1) belongs to a conserved family of membrane receptors known as the tumor necrosis factor receptor or TNFR family (Itoh et al., 1991). Therefore, overexpression of GKN1 could activate Fas, normally expressed at extremely low levels at least in MKN28 cells (Osaki et al., 2001). In fact, the expression of Fas receptor, evaluated by flow cytometry (Figure 6) Western blotting and RT-PCR showed a significant increase. 


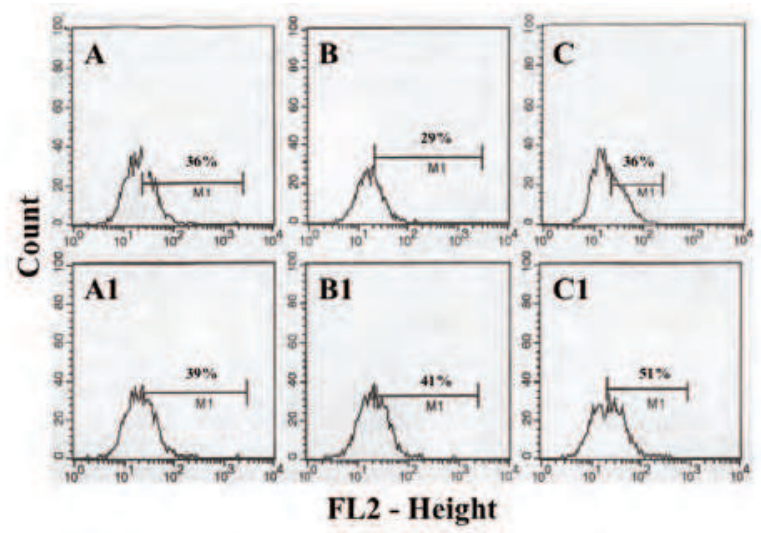

Fig. 6. Flow cytometric analysis of apoptosis in AGS cells. Representative flow cytometry of cells transfected with empty pCDNA 3.1, lipophectamine and GKN1 before (A, B, C) and after (A1, B1, C1) incubation with a monoclonal antibody (IgM) anti-FasL.
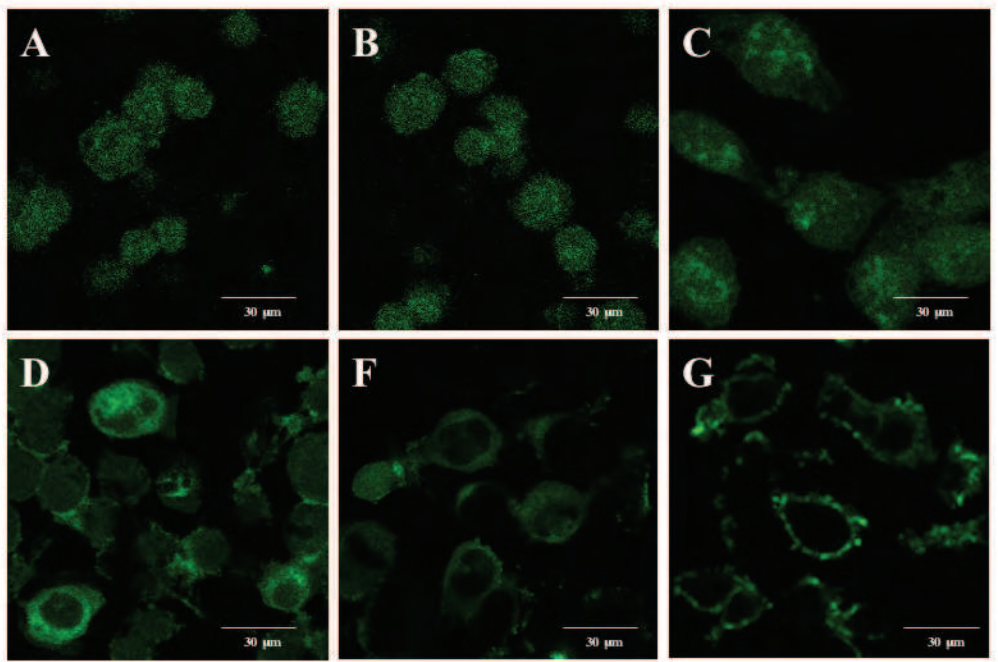

Fig. 7. Confocal microscopy of AGS cells. AGS cells were transfected with pCDNA 3.1 containing the GKN1 cDNA and after 48 hours from transfection cells were analyzed at confocal microscopy in the presence of antibody anti-GKN1 and anti-Fas. A) Untransfected cells. B) Cells treated with lopophectamine. C) Non-premealized transfected cells after incubation with anti-GKN1 antibody. D) Premeabilized transfected cells after incubation with anti-GKN1 antibody. E) Non-premeabilized untransfected cells after incubation with anti-Fas antibody. F) Premeabilized transfected cells after incubation with anti-Fas antibody. 
Fas expression was also analyzed by confocal microscopy. As shown in Fig. 7, compared to the control cells, cells treated with lipophectamine and cells transfected with GKN1 showed, exposure of the permeabilized transfected cells to anti-GKN1 antibody showed a gain in the fluorescent signal that indicated mainly a cytoplasmic distribution of GKN1 protein whereas, the exposure of the transfected cells to anti-Fas antibody showed with respect to untransfected cells a gain in the fluorescent signal that was localized mainly at the level of cell membrane.

Therefore, the increase of Fas expression observed in cells transfected with GKN1 appeared to be specific as also demonstrated by the increase of the Fas mRNA transcription evaluated by RT-PCR (not shown). Fas-mediated apoptosis in gastric cells was also described upon infection by $H$. pylori, however in this case other apoptotic factors are involved as well. These include TRIAL and its receptor subtypes (Yang, et al. 2003; Martin et al., 2004). Because the binding of Fas ligand (FasL) to the Fas antigen results in the transduction of a cytolytic signal into the cell followed by apoptosis, cells overexpressing GKN1 showed an increase in apoptosis that is mainly due to the exposure of the MKN28 cells to FasL with respect to that observed in the absence of FasL. In addition, when FasL binds to Fas, intracellular death caspases are activated, resulting in apoptotic demise of the cell (Chen et al., 1999). Also in cells transfected with GKN1, we observed the proteolytic activation of caspase-3, normally present as a $32 \mathrm{kDa}$ inactive precursor (Zou et al., 1997), as evaluated by Western blot and fluorimetric assay, was observed thus indicating that GKN1-transfected cells were signaled to die (Nicholson et al., 1995; Schlegel et al., 1996; Wang et al., 1996).

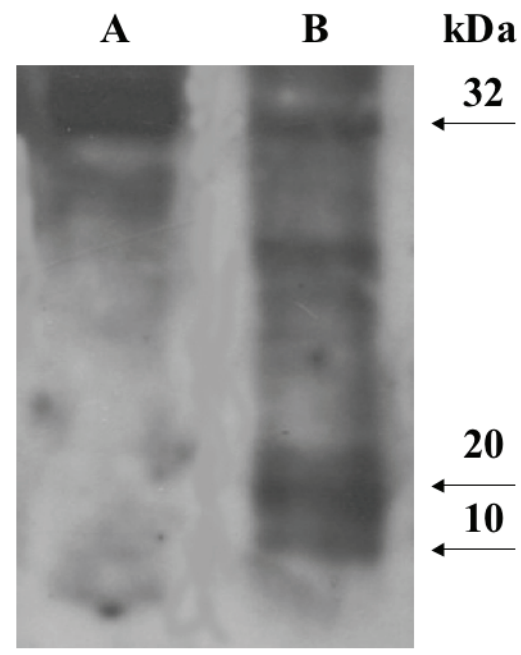

Fig. 8. Western blot of caspase-3. Evaluation of caspase-3 activation in AGS cells before (A) and after (A) $48 \mathrm{~h}$ transfection with GKN1 and exposure to FasL. 
In addition, Yoon et al., 2011, found that transfection of GKN1 in AGS cells showed activation of apoptosis related proteins, including cleaved caspase 3 , caspase 8 and PARP. The GKN1-induced apoptosis is suppressed by the presence of caspase- 3 and caspase- 8 inhibitors.

\section{Conclusion}

We have evaluated the expression of GKN1 in normal and unhealthy tissues and found that the GKN1, both at protein and mRNA levels, is down-regulated in human specimens from H. pylori infected gastric mucosa or absent in gastric GC tissues or cells. GKN1 is instead normally present in normal tissues and cells or in the peritumoral area of GC. Also the immunohistochemical analysis of human specimens (normal tissues, intestinal metaplasia, GC) showed a progressive decrease of GKN1 expression thus suggesting that GKN1 could be a good biomarker candidate for gastric cancer progression.

In addition, our studies on the overexpression of the protein in gastric cancer cell lines showed that GKN1 could act as modulator of apoptosis and suggested a possible role of GKN1 as a tumor suppressor gene. The modulation of apoptotic signals by GKN1 during the early stages of acute gastric injury may have a profound influence on tissue repair and be instrumental in determining the individual host response.

\section{Acknowledgements}

This work was supported by funds from the Ministero della Salute, Regione Calabria, 2003.

\section{References}

Baek, H.Y., Lim J.W., Kim, H., Kim, J.M., Kim, J.S., Jung, H.C. \& Kim, K.H. (2004) OxidativeStress-Related Proteome Changes In Helicobacter Pylori-Infected Human Gastric Mucosa. Biochemical Journal, Vol. 379(Pt 2); Apr 15, 2004, pp. 291-299, ISSN 02646021.

Baus-Loncar, M., Lubka, M., Pusch, C.M., Otto, W.R., Poulsom, R. \& Blin, N. (2007). Cytokine Regulation of the Trefoil Factor Family Binding Protein GKN2 (GDDR/TFIZ1/blottin) in Human Gastrointestinal Epithelial Cells. Cellular Physiology and Biochemistry, Vol. 20, No. 1-4, 2007, pp. 193-20, ISSN 1015-8987.

Bruce, R., Westley, S., Griffin, M. \& May, F.E.B. (2005). Interaction between TFF1, a Gastric Tumor Suppressor Trefoil Protein, and TFIZ1, a Brichos Domain Containing Protein with Homology to SP-C. Biochemistry, Vol. 44, No. 22, pp. 7967-75. ISSN 0006-2960.

Carvalho, R., Kayademir, T., Soares, P., Canedo, P., Sousa, S., Oliveira, C., Leistenschneider, P., Seruca, R., Gött, P., Blin, N., Carneiro, F. \& Machado, J.C. (2002). Loss of heterozygosity and promoter methylation, but not mutation, may underlie loss of TFF1 in gastric carcinoma. Laboratory Investigation, Vol. 82, No. 10 Oct 2002, pp. 1319-1326. ISSN 0023-6837. 
Chen, M.K., Strande, L.F., Beierle, E.A., Kain, M.S., Geldziler, B.D. \& Doolin, E.J. (1999). FasMediated Induction of Hepatocyte Apoptosis in a Neuroblastoma and Hepatocyte Coculture Model. Journal of Surgical Research, Vol. 84, No. 1, Jun 1999, pp. 82-87. ISSN 0022-4804.

Correa, P. (1992). Human gastric carcinogenesis: a multistep and multifactorial process-First American Cancer Society Award Lecture on Cancer Epidemiology and Prevention. Cancer Research, Vol. 52, No. 24, Dec 15, 1992, pp. 6735-6740. ISSN 00085472.

Correa, P. (1995). Helicobacter pylori and gastric carcinogenesis. American Journal of Surgical Pathology, Vol.19, Suppl 1, pp. S37-43. ISSN 0147-5185.

Correa, P. \& Piazuelo, M.B. (2008). Natural history of Helicobacter pylori infection. Digestive and Liver Disease, Vol. 40, No. 7, Jul 2008, pp. 490-6. ISSN 1590-8658.

Du, J.J., Dou, K.F., Peng, S.Y., Wang, W.Z., Wang, Z.H., Xiao, H.S., Guan, W.X., Liu, Y.B. \& Gao, Z,Q. (2003). Down-regulated full-length novel gene GDDR and its effect on gastric cancer. Zhonghua Yi Xue Za Zhi, Vol. 83, No. 10, Jul 2003, pp. 1166-1168. ISSN 1003-9406.

El-Omar, E.M., Rabkin, C.S., Gammon, M.D., Vaughan, T.L., Risch, H.A., Schoenberg, J.B., Stanford, J.L., Mayne, S.T., Goedert, J., Blot, W.J., Fraumeni, J.F. Jr \& Chow, W.H. (2003). Increased risk of noncardia gastric cancer associated with proinflammatory cytokine gene polymorphisms. Gastroenterology, Vol. 124, No. 5, May 2003, pp. 1193-1201. ISSN 0016-5085.

Forman, D., Newell, D.G., Fullerton, F., Yarnell, J.W., Stacey, A.R., Wald, N. \& Sitas, F. (1991). Association between infection with Helicobacter pylori and risk of gastric cancer: evidence from prospective investigation. British Medical Journal, Vol. 302, N0. 6788, Jun 1, 1991, pp. 1302-1305. ISSN 09598138

Goldstone, A.R., Quirke, P. \& Dixon, M,F. (1996). Helicobacter pylori infection and gastric cancer. Journal of Pathology, Vol. 179, No. 2, Jun 1996, pp. 129-137. ISSN 0022-3417.

Holcombe, C. (1992). Helicobacter pylori: the African enigma. Gut, Vol. 33, No. 4, Apr 1992, pp. 429-431. ISSN 0017-5749.

Huang, Q., Huang, Q., Chenn, W., Wang, L., Lin, W., Lin, J. \& Lin, X. (2008). Identification of transgelin as a potential novel biomarker for gastric adenocarcinoma based on proteomics technology. Journal of Cancer Research and Clinical Oncology, Vol. 134, No. 11, Nov 2008, pp. 1219-1227. ISSN 0171-5216.

Itoh, N. \& Nagata, S. (1993). A novel protein domain required for apoptosis. Mutational analysis of human Fas antigen. Journal of Biological Chemistry, Vol. 268, No. 15, May 25, 1993, pp. 10932-10937. ISSN 0021-9258.

Itoh, N., Yonehara, S., Ishii, A., Yonehara, M., Mizushima, S., Sameshima, M., Hase, A., Seto, Y. \& Nagata, S. (1991). The polypeptide encoded by the cDNA for human cell surface antigen Fas can mediate apoptosis. Cell, Vol. 66, No. 2, Jul 26, 1991, pp. 233243. ISSN 0092-8674.

Jang, J.S., Cho, H.Y., Lee, Y.J., Ha, W.S. \& Kim, H.W. (2004). The differential proteome profile of stomach cancer: identification of the biomarker candidates. Oncology research. Vol. 14, N0. 10, pp. 491-499. ISSN 965-0407. 
Lands, S.H., Murray, T. \& Bolden, S. (1998). Cancer statistics. Ca Cancer Journal for Clinicians, Vol. 48, No. 1, Jan/Feb 1998, pp. 6-29. 0007-9235.

Martin, J.H., Potthoff, A., Ledig, S., Cornberg, M., Jandl, O., Manns, M.P., Kubicka, S., Flemming, P., Athmann, C., Beil, W. \& Wagner, S. (2004). Effect of H. pylori on the Expression of TRAIL, FasL and their Receptor Subtypes in Human Gastric Epithelial Cells and their Role in Apoptosis. Helicobacter, Vol. 9, No. 5, Oct 2004, pp. 371-386. ISSN 1083-4389.

Martin, T.E., Powell, C.T., Wang, Z., Bhattacharyya, S., Walsh-Reitz, M.M., Agarwal, K. \& Toback, F.G. (2003). A novel mitogenic protein that is highly expressed in cells of the gastric antrum mucosa. American Journal of Physiology Gastrointestinal and Liver Physiology, Vol. 285, No. 2, Jul 2003, pp. G332-343. ISSN 0193-1857.

Menheniott, T.R., Peterson, A.J., O'connor, L., Lee, K.S., Kalantzis, A., Kondova, I., Bontrop, R.E., Bell, K.M. \& Giraud, AS. (2010). A Novel Gastrokine in Mammals Marks Gastric Atrophy and shows evidence of adaptive gene loss in human. Gastroenterology, Vol. 138, No. 5, May 2010, pp. 1823-1835. ISSN 0016-5085.

Moss, S.F., Lee, J.W., Sabo, E., Rubin, A.K., Rommel, J., Westley, B.R., May, F.E., Gao, J., Meitner, P.A., Tavares, R. \& Resnick, M.B. (2008). Decreased expression of gastrokine 1 and trefoil Factor Interacting Protein TFIZ1/GKN2 in gastric cancer: influence of tumor histology and relationship to prognosis. Clinical Cancer Research, Vol. 14, No. 13, Jul 1, 2008, pp. 4161-4167. ISSN 1078-0432.

Motoyama, T., Hojo, H., \& Watanabe, H. (1986). Comparison of seven cell lines derived from human gastric carcinomas. Acta Pathologica Japonica, Vol. 36, No. 1, Jan 1986, pp. 6583. ISSN 0001-6632.

Nabewera, H.M. \& Logan, R.P. (1999). Epidemiology of Helicobacter pylori infection: transmission, translocation and extragastric reservoirs. Journal of Physiology and Pharmacology, Vol. 50, No. 5, Dec 1999, pp. 711-722. ISSN 0867-5910.

Nagata, S. (1996). Apoptosis by death factor. Cell, Vol. 88, No. 3, Feb 7, 1996, pp. 355-365. ISSN 0092-8674.

Nardone, G., Martin, G., Rocco, A., Rippa, E., La Monica, G., Caruso, F. \& Arcari, P. (2008). Molecular expression of gastrokine 1 in normal mucosa and in Helicobacter pylorirelated preneoplastic and neoplastic gastric lesions. Cancer Biology and Therapy, Vol. 7, No. 12, Dec 2008, pp. 1890-1895. ISSN 1538-4047.

Nardone, G., Rippa, E., Martin, G., Rocco, A., Siciliano, R.A., Fiengo, A. Cacace, G., Malorni, A., Budillon, G. \& Arcari, P. (2007). Gastrokine 1 expression in patients with and without Helicobacter pylori infection. Digestive and Liver Disease, Vol. 39, No. 2, Feb 2007, pp. 122-129. ISSN 1590-8658.

Nicholson, W.D., Ali, A., Thornberry, N.A., Vailancourt, J.P., Ding, C.K., Gallant, M., Gareau, Y., Griffin, P.R., Labelle, M., Lazebnik, Y.A., Munday, N.A., Raji, S.M., Smulson, M.E., Yamin, T.T., Yu, V.L. \& Miller, D.K. (1995). Identification and inhibition of the ICE/CED-3 protease necessary for mammalian apoptosis. Nature, Vol. 376, No. 6535, Jul 6, 1995, pp. 37-43. ISSN 0028-0836.

Oien, K.A., McGregor, F., Butler, S., Ferrier, R.K., Downie, I., Bryce, S., Burns, S. \& Keith, W.N. (2004). Gastrokine 1 is abundantly and specifically expressed in superficial gastric epithelium, down-regulated in gastric carcinoma, and shows high 
evolutionary conservation. Journal of Pathology, Vol. 203, No. 3, Jul 2004, pp. 789797. ISSN 0022-3417.

Osaki, M., Kase, S., Kodani, I., Watanabe, M., Adachi, H. \& Ito, H. (2001). Expression of Fas and Fas ligand in human gastric adenomas and intestinal-type carcinomas: correlation with proliferation and apoptosis. Gastric Cancer, Vol. 4, No. 4, pp. 198205. ISSN 1436-3291.

Otto, W.R., Patel, K., McKinnell, I., Evans, M.D., Lee, C.Y., Frith, D., Hanrahan, S., Blight, K., Blin, N., Kayademir, T., Poulsom, R., Jeffery, R., Hunt, T., Wright, N.A., McGregor, F. \& Oien, K.A. (2006). Identification of blottin: A novel gastric trefoil factor family2 binding protein. Proteomics, Vol. 6, No. 15, Aug 2006, pp. 4235-4245. ISSN 16159853.

Parsonnet, J., Friedman, G.D., Oremtreich, N. \& Vogelman, H. (1997). Risk for gastric cancer in people with CagA positive or CagA negative Helicobacter pylori infection. Gut, Vol. 40, No. 3, Mar 1997, pp. 297-301. ISSN 0017-5749.

Pisani, P., Parkin, D.M., Bray, F. \& Ferlay, J. (1999). Estimates of the worldwide mortality from 25 cancers in 1990. International Journal of Cancer, Vol. 83, No. 1, Sep 1999, pp. 18-29. ISSN 0020-7136.

Rippa, R., Martin, G., Rocco, A., La Monica, G., Fiengo, A., Siciliano, R.A., Cacace, G., Malorni, A., Nardone, G. \& Arcari, P. (2007). Changes of protein expression in Helicobacter pylori-infected human gastric mucosa. Current Topics in Peptide \& Protein Research. Vol. 8, pp. 35-43. ISSN 0972-4524.

Rippa, E., La Monica, G., Allocca, R., Romano, M.F., De Palma, M. \& Arcari, P. (2010). Overexpression of gastrokine 1 in gastric cancer cells induces fas-mediated apoptosis. Journal of Cellular Physiology, Dec 28, 2010 [Epub ahead of print]. ISSN 0021-9541.

Sanchez-Pulido, L., Devos, D. \& Valencia, A. (2002). BRICHOS: a conserved domain in proteins associated with dementia, respiratory distress and cancer. Trends in Biochemical Science, Vol. 27, No. 7, Jul 2002, pp. 329-332. ISSN 0968-0004.

Schlegel, J., Peters, I., Orrenius, S., Miller, D.K., Thornberry, N.A., Yamin, T.T. \& Nicholson, D.W. (1996). CPP32/apopain is a key interleukin 1 beta converting enzyme-like protease involved in Fas-mediated apoptosis. Journal of Clinical Investigation, Vol. 271, No. 4, Jan 26, 1996, pp. 1841-1844. ISSN 0021-9738.

Segal, E.D., Falkow, S. \& Tompkinset, L.S. (1996). Helicobacter pylori attachment to gastric cells induces cytoskeletal rearrangements and tyrosine phosphorylation of host cell proteins. Proceedings of the National Academy of Sciences USA, Vol. 93, No. 3, Feb 6, 1996, pp. 1259-1264. ISSN 0027-8424.

Shiozaki, K., Nakamori, S., Tsujie, M,, Okami, J., Yamamoto, H., Nagano, H., Dono, K., Umeshita, K., Sakon, M., Furukawa, H., Hiratsuka, M., Kasugai, T., Ishiguro, S. \& Monden, M. (2001). Human stomach-specific gene, CA11, is down-regulated in gastric cancer. International Journal of Oncology, Vol. 19, No. 4, pp. 701-707. ISSN 1019-6439.

Suda, T., Takahashi, T., Golstein, P. \& Nagata, S. (1993). Molecular cloning and expression of the Fas ligand, a novel member of the tumor necrosis factor family. Cell, Vol. 75, No. 6, Dec 15, 1993, pp. 1169-78. ISSN 0092-8674. 
Toback, F.G., Walsh-Reitz, M.M., Musch, M.W., Chang, E.B., Del Valle, J., Ren, H., Huang, E. \& Martin, T.E. (2003). Peptide fragments of AMP-18, a novel secreted gastric antrum mucosal protein, are mitogenic and motogenic. American Journal of Physiology Gastrointestinal and Liver Physiology, Vol. 285, No. 2, Jul 2003, pp. G344G353. ISSN 0193-1857.

Vlahou, A. \& Fountoulakis, M. (2005). Proteomic approaches in the search for disease biomarkers. Journal of Chromatogr B Analytical Technologies in the Biomedical Life Sciences, Vol. 814, No. 1, Jan 5, 2005, pp. 11-19. ISSN 1570-0232.

Walsh-Reitz, M.M., Huang, E.F., Musch. M.W., Chang, E.B., Martin, T.E., Kartha, S. \& Toback, F.G. (2005). AMP18 protects barrier function of colonic epithelial cells: role of tight junction proteins. American Journal of Physiology Gastrointestinal and Liver Physiology, Vol. 289, No. 1, Jul 2005, pp. G163-G171. ISSN 0193-1857.

Wang, X., Zelenski, N.G., Yang, J., Sakai, J., Brown, M.S. \& Goldstein, J.L. (1996). Cleavage of sterol regulatory element binding proteins (SREBPs) by cpp32 during apoptosis. EMBO Journal, Vol. 15, No. 5, Mar 1, 1996, pp. 1012- 1020. ISSN 02614189.

Watanabe, T., Tada, M. \& Nagai, H. (1998). Helicobacter pylori infection induces gastric cancer in Mongolian gerbils. Gastroenterology, Vol. 115, No. 3, Sep 1998, pp. 642-648. ISSN 0016-5085.

Westley, B.R., Griffin, S.M. \& May, F.E. (2005). Interaction between TFF1, a gastric tumor suppressor trefoil protein, and TFIZ1, a brichos domain-containing protein with homology to SP-C. Biochemistry, Vol. 44, No. 22, Jun 7, 2005, pp. 7967-7975. ISSN 0006-2960.

Whary, M.T., Sundina, N., Bravo, L.E., Correa, P., Quinones, F., Caro, F. \& Fox, J.G. (2005). Intestinal helminthiasis in Colombian children promotes a Th2 response to Helicobacter pylori: possible implications for gastric carcinogenesis. Cancer Epidemiology, Biomarkers and Prevention, Vol. 14, Jun 2005, pp. 1464-1469. ISSN 10559965.

Yang, Y., Deng, C.S., Peng, J.Z., Wong, B.C.Y., Lam, S.K. \& Xia, H,H.X. (2003). Effect of Helicobacter pylori on apoptosis and apoptosis related genes in gastric cancer cells. Molecular Pathology, Vol. 56, No. 1, Feb 2003, pp. 19-24. ISSN 1366-8714.

Yoon, J.H., Song, J.H., Zhang, C., Jin, M., Kang, Y.H., Nam, S.W., Lee, J.Y. \& Park, W.S. (2011). Inactivation of gastrokine 1 gene in gastric adenomas and carcinomas. Journal of Pathology. Vol. 223, No. 5, Apr 2011, pp. 618-625. ISSN 00223417.

Yoshihara, T., Kadota, Y., Yoshimura, Y., Tatano, Y., Takeuchi, N., Okitsu, H., Umemoto, A., Yamauchi, T. \& Itoh, K. (2006). Proteomic alteration in gastric adenocarcinomas from Japanese patients. Molecular Cancer. Vol. 5, Dec 25, 2006, 75. ISSN 1476-4598

Yoshikawa, Y., Mukai, H., Hino, F., Asada, K. \& Kato, I. (2000). Isolation of two novel genes, own-regulated in gastric cancer. Japanese Journal of Cancer Research, Vol. 91, No. 5, May 2000, pp. 459-463. ISSN 0910-5050. 
Zou, H., Henzel, W.J., Liu, X., Lutschg, A. \& Wang, X. (1997). Apaf-1, a Human Protein Homologous to C. elegans CED-4, Participates in Cytochrome c-Dependent Activation of Caspase-3. Cell, Vol. 90, No. 3, Aug 8, 1997, pp. 405-413. ISSN 00928674. 


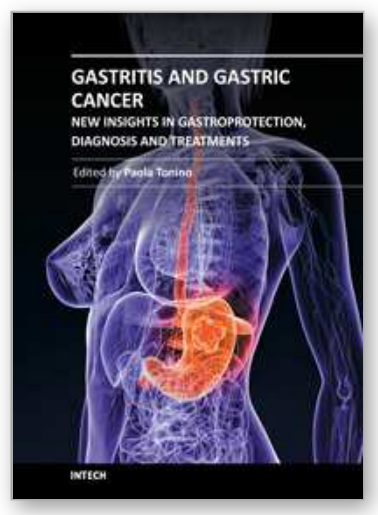

\section{Gastritis and Gastric Cancer - New Insights in Gastroprotection, Diagnosis and Treatments}

Edited by Dr. Paola Tonino

ISBN 978-953-307-375-0

Hard cover, 296 pages

Publisher InTech

Published online 15, September, 2011

Published in print edition September, 2011

This book is a comprehensive overview of invited contributions on Helicobacter pylori infection in gastritis and gastric carcinogenesis. The first part of the book covers topics related to the pathophysiology of gastric mucosal defense system and gastritis including the gastroprotective function of the mucus, the capsaicinsensitive afferent nerves and the oxidative stress pathway involved in inflammation, apoptosis and autophagy in $\mathrm{H}$. pylori related gastritis. The next chapters deal with molecular pathogenesis and treatment, which consider the role of neuroendocrine cells in gastric disease, DNA methylation in $\mathrm{H}$. pylori infection, the role of antioxidants and phytotherapy in gastric disease. The final part presents the effects of cancer risk factors associated with $\mathrm{H}$. pylori infection. These chapters discuss the serum pepsinogen test, $\mathrm{K}$-ras mutations, cell kinetics, and $\mathrm{H}$. pylori lipopolysaccharide, as well as the roles of several bacterial genes (cagA, $\operatorname{cag} \mathrm{T}$, $\operatorname{vacA}$ and dupA) as virulence factors in gastric cancer, and the gastrokine-1 protein in cancer progression.

\section{How to reference}

In order to correctly reference this scholarly work, feel free to copy and paste the following:

Emilia Rippa, Paolo Mallardo and Paolo Arcari (2011). Role of Gastrokine 1 in Gastric Cancer, Gastritis and Gastric Cancer - New Insights in Gastroprotection, Diagnosis and Treatments, Dr. Paola Tonino (Ed.), ISBN: 978-953-307-375-0, InTech, Available from: http://www.intechopen.com/books/gastritis-and-gastric-cancernew-insights-in-gastroprotection-diagnosis-and-treatments/role-of-gastrokine-1-in-gastric-cancer

\section{INTECH}

open science | open minds

\author{
InTech Europe \\ University Campus STeP Ri \\ Slavka Krautzeka 83/A \\ 51000 Rijeka, Croatia \\ Phone: +385 (51) 770447 \\ Fax: +385 (51) 686166 \\ www.intechopen.com
}

\author{
InTech China \\ Unit 405, Office Block, Hotel Equatorial Shanghai \\ No.65, Yan An Road (West), Shanghai, 200040, China \\ 中国上海市延安西路65号上海国际贵都大饭店办公楼 405 单元 \\ Phone: +86-21-62489820 \\ Fax: $+86-21-62489821$
}


(C) 2011 The Author(s). Licensee IntechOpen. This chapter is distributed under the terms of the Creative Commons Attribution-NonCommercialShareAlike-3.0 License, which permits use, distribution and reproduction for non-commercial purposes, provided the original is properly cited and derivative works building on this content are distributed under the same license. 